\title{
MECHANICAL PROPERTIES OF BIO-BASED CONCRETE CONTAINING BLENDED PEACH SHELL AND APRICOT SHELL WASTE
}

\author{
MEHANSKE LASTNOSTI BIOBETONA NA OSNOVI DODATKA \\ MEŠANICE ODPADNIH KOŠČIC BRESKEV IN MARELIC
}

\author{
Fan Wu1 ${ }^{1,2 * *}$, Changwu Liu ${ }^{3,4, *}$, Wei Sun ${ }^{3,4}$, Lianwei Zhang ${ }^{3,4}$ \\ ${ }^{1}$ Sichuan University-The Hong Kong Polytechnic University, Institute of Disaster Management and Reconstruction, no. 24 South Section 1, \\ Yihuan Road, Chengdu 610065, China \\ ${ }^{2}$ Chongqing Jiaotong University, Chongqing Municipal Education Commission, Key Laboratory of Geological Hazards Mitigation for \\ Mountainous Highway and Waterway, no. 66 Xuefu Avenue, Nan'an District, Chongqing 400074, China \\ ${ }^{3}$ Sichuan University, College of Water Resource and Hydropower, no. 24 South Section 1, Yihuan Road, Chengdu 610065, China \\ ${ }^{4}$ Sichuan University, State Key Laboratory of Hydraulics and Mountain River Engineering, no. 24 South Section 1, Yihuan Road, \\ Chengdu 610065, China \\ *liuchangwu@scu.edu.cn,**wu_fan2017@163.com
}

Prejem rokopisa - received: 2018-04-04; sprejem za objavo - accepted for publication: 2018-05-18

doi:10.17222/mit.2018.065

The utilization of industrial and agricultural wastes as aggregates in concrete can reduce the negative impact of concrete on the ecological environment. For manufacturing a more environmentally friendly concrete, a series of specimens was prepared with 0 $\%, 12.5 \%, 25 \%, 37.5 \%$ and $50 \%$ replacement of normal weight aggregate (NWA) and sand by peach shell (PS) and apricot shell (AS), while the other parameters were set as constant. The results showed that for a $50 \%$ replacement of NWA and sand by PS and AS, the 28-day compressive strength, splitting tensile strength, flexural strength and modulus of elasticity of the concrete decreased by $34.3 \%, 28.8 \%, 33.6 \%$ and $31.5 \%$, respectively. However, concrete containing $50 \%$ PS and AS was lighter by $19.37 \%$, which fulfilled the density requirement for lightweight aggregate concrete (LWAC). In addition, the water absorption and porosity of concrete increased by increasing the percentage of blended PS and AS content. Based on the results, the utilization of blended PS and AS as coarse and fine aggregate, respectively, to produce LWAC with acceptable properties seems to be a feasible option.

Keywords: peach shell, apricot shell, bio-based concrete, lightweight aggregate concrete

Uporaba industrijskih in kmetijskih odpadkov kot agregatov (dodatkov) v beton lahko zmanjša njegov negativni vpliv na ekologijo okolja. Avtorji prispevka so zato izdelali bolj okolju prijazen beton. Izdelali so serijo vzorcev z $0 \%, 12,5 \%, 25 \%$, $37,5 \%$ in $50 \%$ dodatkom breskvinih (PS) in mareličnih koščic (AS), kot enakovredno masno zamenjavo za grobo frakcijo kamna (NWA) in finejši pesek, ostali parametri pa so ostali nespremenjeni. Rezultati raziskav so pokazali, da $50 \%$ zamenjava NWA in peska $\mathrm{z}$ mešanico PS in AS, zmanjša 28-dnevno tlačno trdnost, cepilno natezno trdnost, upogibno trdnost in modul elastičnosti betona za $34,3 \%, 28,8 \%, 33,6 \%$ oz. 31,5\%. Vendar je beton, ki vsebuje $50 \%$ PS in AS, lažji za $19,37 \%$ in s tem izpolnjuje zahteve za lahki agregatni beton (LWAC). Dodatno sta se povečali absorpcija vode in poroznost betona s povečevanjem količine mešanice PS in AS. Na osnovi rezultatov avtorji ugotavljajo, da lahko uporaba mešanice PS in AS kot zamenjave za grobo frakcijo kamna in finega peska predstavlja opcijo za izdelavo lahkega agregatnega betona s sprejemljivimi lastnostmi.

Ključne besede: koščice breskev in marelic, biobeton, beton z lahkimi agregati

\section{INTRODUCTION}

Concrete is the most extensive building material used for a variety of civil engineering projects, such as roads, bridges, dams and other buildings. ${ }^{1}$ More than 10 billion tons of concretes is produced per year, and annual production is approximately $1.5 \mathrm{t}$ for each person, ${ }^{2}$ thereby a large number of raw materials around the world need to be used for concrete production each year. ${ }^{3}$ However, the process of obtaining conventional natural aggregates seriously damages the local ecological environment, ${ }^{4}$ and concrete industry has a significant negative impact on the society, the economy and the environment. ${ }^{5}$ An effective way to achieve the sustainable development of concrete is to use industrial and agricultural wastes as aggregate to replaceme normal weight aggregate (NWA). ${ }^{6}$ Because a large amount of concrete is produced each year, even the partial replacement of NWA with industrial and agricultural wastes would be beneficial to the ecological environment.

The development of world economy leads to a drastic increase in industrial and agricultural wastes, which also causes some environmental pollution problem. Recycling of such wastes is an effective way to consider ecological and economic benefits. ${ }^{7}$ Recently, a variety of industrial and agricultural wastes have been used as replacements for normal weight aggregate (NWA) in concrete, such as oil palm shell, palm oil clinker, wood, mussel shell, apricot shell (AS), peach shell (PS) and coconut shell, etc. The use of these wastes in concrete has many advantages, including decreasing the consumption of natural aggregates and recycling these wastes. ${ }^{8}$ In this method, 
concrete can be considered as an environmentally friendly building material. ${ }^{9}$

In China, more than a thousand tons of PS and AS needs to be discharged each year, and they are considered as an agricultural waste in orchards. To recycle these wastes, many researches are on going, such as, Zhu et al. ${ }^{10}$ reported that an effective route including a pyrolysis process and a reductive strategy to synthesize high-performance hard carbons from AS. Kaynak et al. ${ }^{11}$ reported that the combustion characteristics of PS used as fuels, and suggested that the PS is a potential clean energy. Hosseinabady et al. ${ }^{12}$ reported that the use of AS as soil amendments to adsorb some heavy metals from contaminated soil, such as lead, cadmium and nickel, etc. However, the most common way to deal with these wastes is still landfill, and there are very few reports on the use of PS and AS as aggregates for the production of green sustainable concrete.

Due to huge demands for concrete, naturally available NWA is depleting very fast and becoming scarce. PS and AS wastes are an abundant and low-cost natural resource, which can be considered as one of the alternative aggregates in the production of bio-based concrete. ${ }^{13}$ On the one hand, PS and AS wastes are difficult to be biodegradable in a natural condition, and weather resistant are better than other agricultural waste. On the other hand, PS and AS wastes are lighter than that of NWA, which can be used as a lightweight aggregate in concrete and significantly reduce the density of concrete. Furthermore, they are renewable aggregate resources that can be continuously supplied from agricultural processing plants. Previous researches mainly focused on the utilization of single type of waste as a substitute for coarse NWA, and there is less literature about the effect of using two types of different wastes to replace the coarse and fine aggregate in concrete simultaneously, especially the incorporation of blended PS and AS in bio-based concrete.

The purpose of this study was to investigate the mechanical properties of bio-based concrete containing blended PS and AS waste. Different percentages (0\%, $12.5 \%, 25 \%, 37.5 \%$ and $50 \%$ ) of PS and AS were used as a replacement for the coarse NWA and sand, respectively. The properties investigated include workability, density, compressive strength, splitting tensile strength, flexural strength, modulus of elasticity, water absorption and porosity.

\section{MATERIALS AND METHODS}

\subsection{Materials}

\subsubsection{Cement}

Type-I 42.5 grade ordinary Portland cement was used as a binder in this study and it was obtained from a local cement company. The Blaine specific surface area and specific gravity of the cement are $3532 \mathrm{~cm}^{2} / \mathrm{g}$ and $3.14 \mathrm{~g} / \mathrm{cm}^{3}$, respectively.

\subsubsection{Aggregates}

Peach shell (PS) and normal weight aggregate (NWA) were used as the coarse aggregate. Apricot shell (AS) and local river sand were used as the fine aggregate. The physical properties of these aggregates are shown in Table 1. The crushed PS and AS aggregate was flaky in shape, its inner surface was smooth, while the outer surface was irregular and rough, as shown in Figure 1. They were collected from a local orchard, and before use they were cleaned and the residual dried pulp and the dust on their surface were removed. Then the dried PS and AS were crushed with a crushing machine. Crushed PS and AS were sieved with $2.36 \mathrm{~mm}, 4.75 \mathrm{~mm}$ and $9.5 \mathrm{~mm}$ sieves. PS particles between $4.75 \mathrm{~mm}$ and $9.5 \mathrm{~mm}$ were considered as a substitute for coarse aggregate, and AS particles between $2.36 \mathrm{~mm}$ and 4.75 $\mathrm{mm}$ were considered as a substitute for fine aggregate.

Table 1: Physical properties of the aggregate.

\begin{tabular}{|l|c|c|c|c|}
\hline \multirow{2}{*}{ Physical property } & \multicolumn{2}{|c|}{ Coarse aggregate } & \multicolumn{2}{c|}{ Fine aggregate } \\
\cline { 2 - 5 } & NWA & PS & Sand & AS \\
\hline $\begin{array}{l}\text { Maximum size } \\
(\mathrm{mm})\end{array}$ & 12 & 10 & - & 5 \\
\hline $\begin{array}{l}\text { Specific gravity } \\
\left(\mathrm{g} / \mathrm{cm}^{3}\right)\end{array}$ & 2.66 & 1.26 & 2.65 & 1.42 \\
\hline Fineness modulus & 4.9 & 5 & 2.7 & 5 \\
\hline Bulk density (kg/m $\left.)^{3}\right)$ & 1449 & 536 & 1560 & 600 \\
\hline $\begin{array}{l}\text { Water absorption } \\
(24 \text { h) }(\%)\end{array}$ & 0.5 & 16.7 & 1.2 & 13.8 \\
\hline $\begin{array}{l}\text { Aggregate impact } \\
\text { value (\%) }\end{array}$ & 17.71 & 1.95 & - & 2.95 \\
\hline $\begin{array}{l}\text { LA abrasion value } \\
(\%)\end{array}$ & 22.54 & 6 & - & 6.82 \\
\hline Flakiness index $(\%)$ & 18 & 41 & - & 48 \\
\hline Surface texture & Rough & $\begin{array}{c}\text { Smooth\& } \\
\text { rough }\end{array}$ & - & $\begin{array}{c}\text { Smooth\& } \\
\text { rough }\end{array}$ \\
\hline Shape & Angular & Flaky & Rounded & Flaky \\
\hline
\end{tabular}
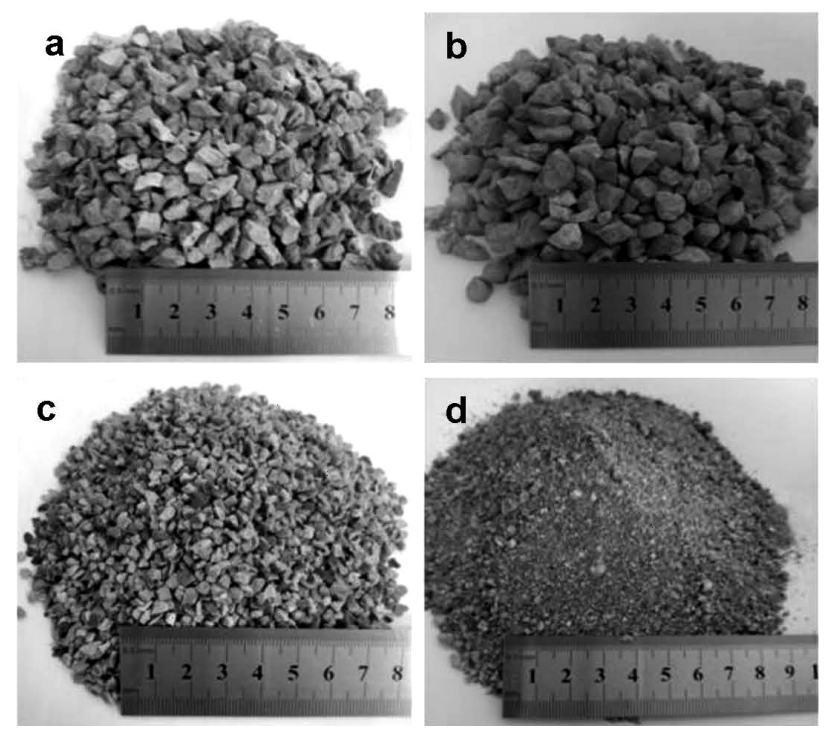

Figure 1: a) Crushed PS aggregate (4.75-9.5mm), b) NWA, c) crushed AS aggregate $(2.36-4.75 \mathrm{~mm})$ and d) river sand 

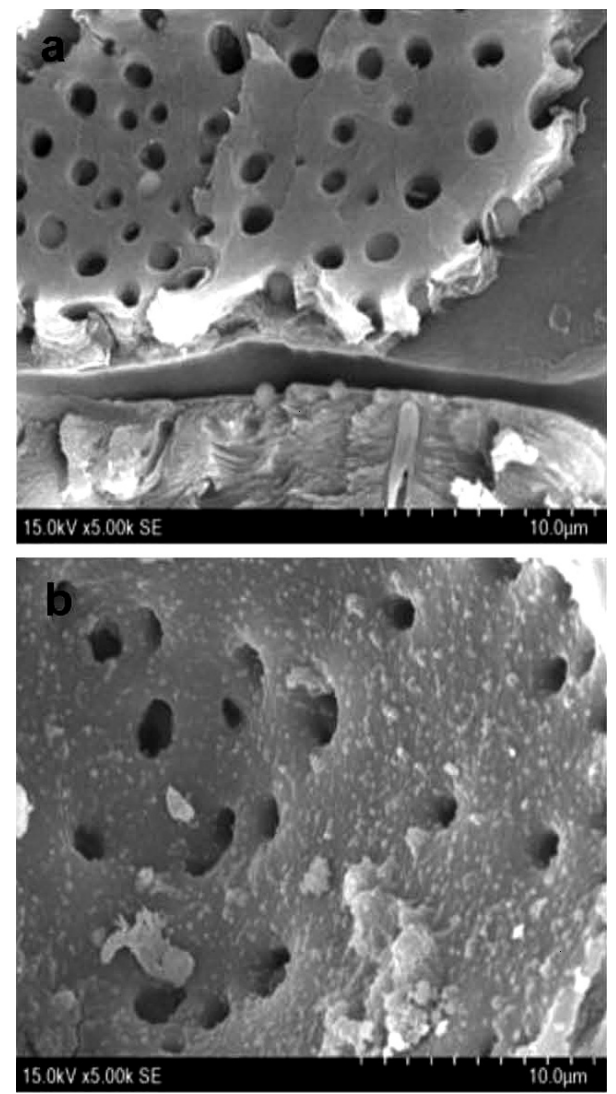

Figure 2: SEM image of powdery PS and AS at $5000 \times$ magnification a) PS and b) AS

Scanning electron microscopy (SEM) images of powdery PS and AS at $5000 \times$ magnification are shown in Figure 2. Both PS and AS have many microscopic pore structures, and the PS has more porosity than AS, which results in a specific gravity of PS lower than that of AS. Due to the presence of pores, it also leads to high water absorption of PS and AS, compared to the NWA. Therefore, they were pre-soaked in water and kept saturated and the surface in dry condition before mixing.

\subsubsection{Superplasticizer}

The naphthalene sulphonated superplasticizer (SP) was used to improve the workability of concrete. For all mixes, the content of SP was $1 \%$ of the weight of cement.

\subsubsection{Water}

Normal tap water was used in this study and a water-to-cement $(\mathrm{w} / \mathrm{c})$ ratio of 0.35 was used for all mixes.

\subsection{Mix Proportioning and Specimen Preparation}

The mix proportion of all the mixes is shown in Table 2. A control mix without any PS and AS was also prepared for comparison (P0). NWA was replaced with PS and sand was replaced with AS by volume, respectively. The volume percentages of sand and NWA replaced by AS and PS were the same, and they were $0 \%, 2.5 \%, 25 \%, 37.5 \%$ and $50 \%$, respectively. Specimens were prepared according to the procedure prescribed in GB50081-2002. Specimens were removed from the mold after $24 \mathrm{~h}$, they were stored in a controlled room with a relative humidity of $95 \% \pm 5 \%$ and a temperature of $20^{\circ} \mathrm{C} \pm 2{ }^{\circ} \mathrm{C}$ until the test age.

\subsection{Test Methods}

The workability of all the mixtures was measured using the slump test according to ASTM C143/ C143M-12. The compressive strength test and splitting tensile strength test were performed according to GB/T 50080-2016. The flexural strength test and modulus of elasticity were measured in accordance with ASTM C78-10 and ASTM C469-10, respectively. In addition, the density was determined according to ASTM C138/ C138-14M. Water absorption and porosity were tested according to the procedures prescribed in ASTM C642. The average value of at least three specimens was taken for each test result.

\section{RESULTS AND DISCUSSION \\ 3.1 Workability}

Relationship between blended PS and AS content and slump value is shown in Figure 3. The results showed that the slump of concrete decreased with an increase of the blended PS and AS content. P0 mix had a slump value of $103 \mathrm{~mm}$, and the slump values of P12.5, P25, P37.5 and P50 mixes were $80 \mathrm{~mm}, 55 \mathrm{~mm}, 45 \mathrm{~mm}$ and $35 \mathrm{~mm}$, respectively, which reduced by $22.3 \%, 46.6 \%$, $56.3 \%$ and $66.0 \%$, respectively, compared to the P0 mix. This may contribute to the flakiness index of PS

Table 2: Mix proportion of concrete $\left(\mathrm{kg} / \mathrm{m}^{3}\right)$

\begin{tabular}{|c|c|c|c|c|c|c|c|c|c|c|}
\hline \multirow[b]{2}{*}{ Mix code } & \multirow[b]{2}{*}{ Cement } & \multirow[b]{2}{*}{ Water } & \multirow[b]{2}{*}{$\mathrm{W} / \mathrm{C}$} & \multirow[b]{2}{*}{$\mathrm{SP}$} & \multicolumn{3}{|c|}{ Fine aggregate } & \multicolumn{3}{|c|}{ Coarse aggregate } \\
\hline & & & & & Sand & AS & $\begin{array}{c}\text { AS/total fine } \\
\text { aggregate ratio }\end{array}$ & NWA & PS & $\begin{array}{l}\text { PS/total coarse } \\
\text { aggregate ratio }\end{array}$ \\
\hline P0 & 550 & 192.5 & 0.35 & 5.5 & 780 & 0 & 0 & 1000 & 0 & 0 \\
\hline P12.5 & 550 & 192.5 & 0.35 & 5.5 & 682.5 & 37.5 & $12.5 \%$ & 875 & 46.25 & $12.5 \%$ \\
\hline $\mathrm{P} 25$ & 550 & 192.5 & 0.35 & 5.5 & 585 & 75 & $25 \%$ & 750 & 92.5 & $25 \%$ \\
\hline P37.5 & 550 & 192.5 & 0.35 & 5.5 & 487.5 & 112.5 & $37.5 \%$ & 625 & 138.75 & $37.5 \%$ \\
\hline P50 & 550 & 192.5 & 0.35 & 5.5 & 390 & 150 & $50 \%$ & 500 & 185 & $50 \%$ \\
\hline
\end{tabular}




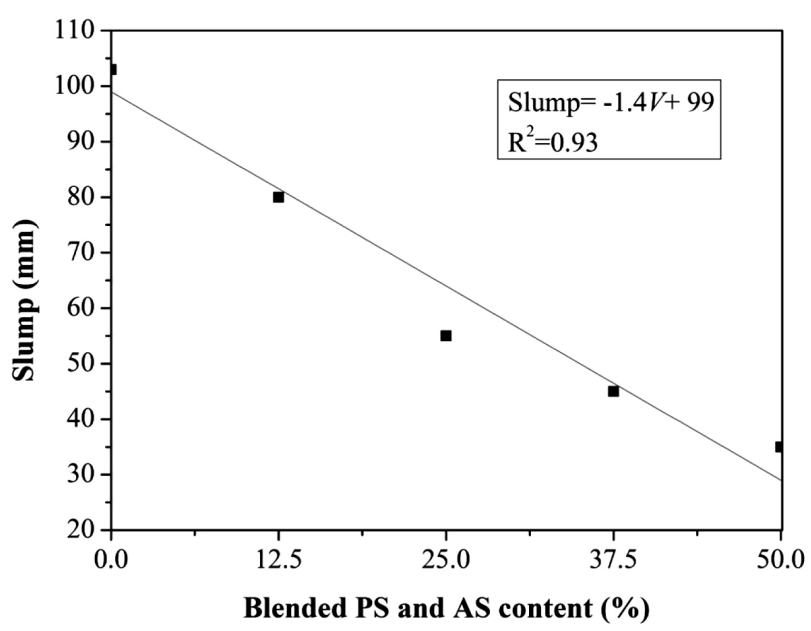

Figure 3: Relationship between blended PS and AS content and slump value

and AS being higher than that of NWA, the irregular angular texture of PS leads to lower fluidity, and reduces the slump value of fresh concrete.

\subsection{Density}

The relationship between blended PS and AS content and density is shown in Figure 4. The results showed that the three types of density of concrete tended to decrease as an increase in blended PS and AS content due to the specific gravity of PS and AS being lower than that of NWA. If only the oven dry density (ODD) was considered, the ODD of concrete varied from $2370 \mathrm{~kg} / \mathrm{m}^{3}$ to $1911 \mathrm{~kg} / \mathrm{m}^{3}$, and they were $6.29 \%, 10.68 \%, 16.16 \%$ and $19.37 \%$ lighter than the control concrete (P0), respectively. Lightweight aggregate concrete (LWAC) is defined as a type of special concrete with a density in the range $1600-2000 \mathrm{~kg} / \mathrm{m}^{3}$ and a compressive strength of more than $15 \mathrm{MPa},{ }^{14}$ and concrete containing $37.5 \%$ and $50 \%$ blended PS and AS fulfills the density requirement of LWAC.

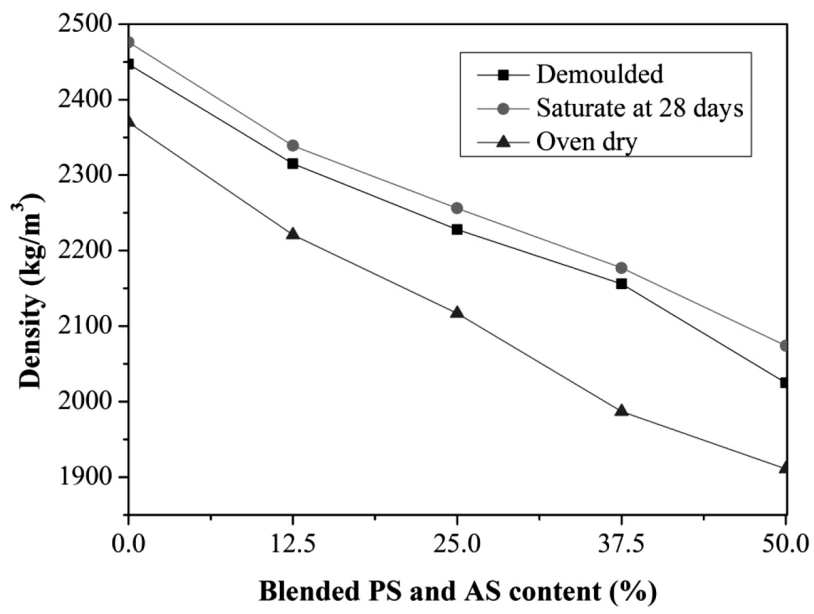

Figure 4: Relationship between blended PS and AS content and density

\subsection{Compressive Strength}

Table 3 shows the compressive strength of the concrete. The test results showed that the replacement of NWA and sand with PS and AS, respectively, reduced the compressive strength of concrete at ages of $(3,7,28$, and 56) $\mathrm{d}$. The compressive strength decreased as an increase in blended PS and AS content due to the strength and stiffness of PS and AS being lower than that of the NWA. Compared to the control concrete (P0), the P12.5, P25, P37.5 and P50 mixes showed $11.9 \%$, $19.0 \%, 27.9 \%$ and $34.3 \%$ lower compressive strength at $28 \mathrm{~d}$, respectively. In addition, concrete containing blended PS and AS attained approximately $67.7 \%$ to $78.7 \%$ of compressive strength at $3 \mathrm{~d}$, and $76.8 \%$ to $87.9 \%$ of compressive strength at $7 \mathrm{~d}$. However, the control concrete $(\mathrm{P} 0)$ attained approximately $80.8 \%$ of compressive strength at $3 \mathrm{~d}$ and $92.8 \%$ of compressive strength at $7 \mathrm{~d}$. This indicated that the incorporation of PS and AS in the concrete reduced the early compressive strength of the concrete. This may be because PS and AS are organic materials, which weakens the cohesiveness between PS and AS aggregate and cement paste, and eventually, the early compressive strength was decreased.

Table 3: Compressive strengths of concretes

\begin{tabular}{|c|c|c|c|c|c|}
\hline \multirow{2}{*}{$\begin{array}{c}\text { Mix } \\
\text { code }\end{array}$} & \multicolumn{2}{|c|}{ Compressive strength $(\mathrm{MPa})$} & \multirow{2}{*}{$\begin{array}{c}\text { \% decrease in } \\
\text { compressive } \\
\text { strength }(28 \mathrm{~d})\end{array}$} \\
\cline { 2 - 5 } P0 & $\begin{array}{c}37.9 \\
(80.8 \%)\end{array}$ & $\begin{array}{c}43.5 \\
(92.8 \%)\end{array}$ & 46.9 & $\begin{array}{c}49.5 \\
(105.5 \%)\end{array}$ & - \\
\hline P12.5 & $\begin{array}{c}32.5 \\
(78.7 \%)\end{array}$ & $\begin{array}{c}36.3 \\
(87.9 \%)\end{array}$ & 41.3 & $\begin{array}{c}46.2 \\
(111.9 \%)\end{array}$ & 11.9 \\
\hline P25 & $\begin{array}{c}25.7 \\
(67.7 \%)\end{array}$ & $\begin{array}{c}29.2 \\
(76.8 \%)\end{array}$ & 38.0 & $\begin{array}{c}41.0 \\
(107.9 \%)\end{array}$ & 19.0 \\
\hline P37.5 & $\begin{array}{c}23.1(68.3 \\
\%)\end{array}$ & $\begin{array}{c}26.0 \\
(76.9 \%)\end{array}$ & 33.8 & $\begin{array}{c}35.8 \\
(105.9 \%)\end{array}$ & 27.9 \\
\hline P50 & $\begin{array}{c}22.4 \\
(72.7 \%)\end{array}$ & $\begin{array}{c}24.0 \\
(77.9 \%)\end{array}$ & 30.8 & $\begin{array}{c}33.5 \\
(108.8 \%)\end{array}$ & 34.3 \\
\hline
\end{tabular}

Note: Values in bracket denote the percentages of compressive strength to the corresponding 28-day compressive strength.

The relationship between the compressive strength at age of $28 \mathrm{~d}$ and the compressive strength at early ages of (3 and 7) d are shown in Figure 5. Equation (1) and Equation (2) show the linear relationship has a good correlation coefficient between the compressive strength at age of (3 and 7) d and the compressive strength at age of $28 \mathrm{~d}$, respectively:

$$
\begin{gathered}
\left(f_{\text {cu }}\right)_{28}=0.81\left(f_{\text {cu }}\right)_{3}+14.7 \\
\left(f_{\text {cu }}\right)_{28}=0.63\left(f_{\text {cu }}\right)_{7}+17.24
\end{gathered}
$$

Where $\left(f_{\mathrm{cu}}\right)_{3},\left(f_{\mathrm{cu}}\right)_{7}$ and $\left(f_{\mathrm{cu}}\right)_{28}$ are the cube compressive strength of the concretes at ages of $(3,7$ and 28) $d$ (in $\mathrm{MPa}$ ), respectively.

\subsection{Splitting Tensile and Flexural Strength}

The splitting tensile and flexural strength of concrete are shown in Table 4. Concrete containing blended PS 


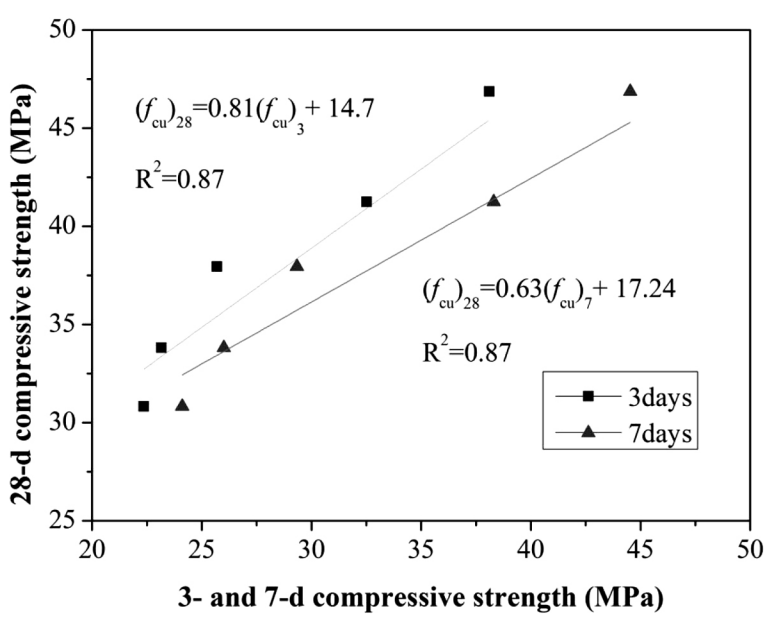

Figure 5: Relationship between early age (3 and 7)-day and 28-day compressive strength

and AS showed lower splitting tensile and flexural strength than the control concrete (P0), and the splitting tensile strength of P12.5, P25, P37.5 and P50 mixes decreased by $8.1 \%, 14.7 \%, 25.6 \%$ and $28.8 \%$, respectively, and the flexural strength reduced by $4.4 \%$, $13.0 \%, 26.4 \%$ and $33.6 \%$, respectively, compared to the control concrete. Generally, due to the low tensile strength of the concrete, it tends to develop microscopic cracks in the tensile stress condition, and these microscopic cracks can easily propagate and penetrate into macroscopic cracks under continuous loads, and eventually leading to the concrete failure. ${ }^{15}$ The minimum value of splitting tensile strength at age of $28 \mathrm{~d}$ for LWAC is $2.0 \mathrm{MPa} .{ }^{16}$ Based on the results, all the mixes in this study had splitting tensile strength of more than 2.0 $\mathrm{MPa}$.

Table 4: Splitting tensile and flexural strength and modulus of elasticity of concrete.

\begin{tabular}{|c|c|c|c|}
\hline Mix code & $\begin{array}{c}\text { Splitting } \\
\text { tensile strength } \\
(\mathrm{MPa})\end{array}$ & $\begin{array}{c}\text { Flexural } \\
\text { strength (MPa) }\end{array}$ & $\begin{array}{c}\text { Modulus of } \\
\text { elasticity } \\
(\mathrm{GPa})\end{array}$ \\
\hline P0 & 2.86 & 4.32 & 15.93 \\
\hline P12.5 & 2.62 & 4.13 & 15.21 \\
\hline P25 & 2.43 & 3.76 & 13.86 \\
\hline P37.5 & 2.12 & 3.18 & 11.36 \\
\hline P50 & 2.03 & 2.87 & 10.91 \\
\hline
\end{tabular}

According to the linear regression analysis, an effective relationship between the splitting tensile strength and flexural strength and blended PS and AS content, respectively, as shown in Equation (3) and Equation (4), is established from Figure 6.

$$
\begin{aligned}
& f_{\mathrm{t}}=-0.017 V+2.83 \\
& f_{\mathrm{r}}=-0.031 V+4.43
\end{aligned}
$$

where $f_{\mathrm{r}}$ is the splitting tensile strength of concrete $(\mathrm{MPa}), f_{\mathrm{r}}$ is the flexural strength of concrete $(\mathrm{MPa})$, and $V$ is the blended PS and AS content (\%).

It is very important to predict the splitting tensile strength from the compressive strength. Equation (5) and

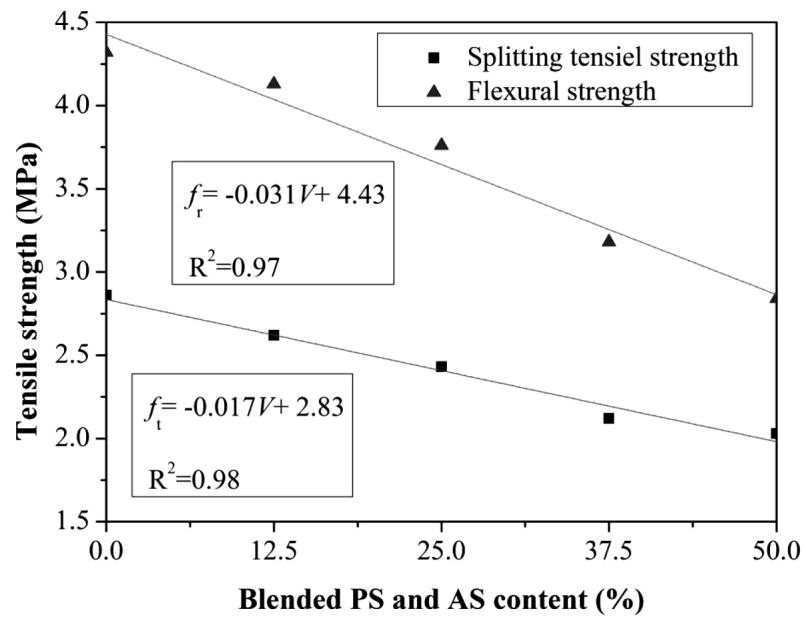

Figure 6: Relationship between blended PS and AS content and tensile strength

Equation (6) established from Figure 7 can be used for accurately predicting the splitting tensile strength and flexural strength from compressive strength, respectively.

$$
\begin{gathered}
f_{\mathrm{t}}=0.09 f_{\mathrm{cu}}^{0.91} \\
f_{\mathrm{r}}=0.09 f_{\mathrm{cu}}^{0.99} \#
\end{gathered}
$$

where, $f_{\mathrm{t}}$ is the 28-day splitting tensile strength $(\mathrm{MPa}), f_{\mathrm{r}}$ is the 28-day flexural strength $(\mathrm{MPa}), f_{\mathrm{cu}}$ is the 28-day cube compressive strength $(\mathrm{MPa})$.

\subsection{Modulus of Elasticity}

Table 4 shows the MOE for all the concretes, which ranges between $10.91 \mathrm{GPa}$ and $15.93 \mathrm{GPa}$. The results showed that the incorporation of PS and AS in concrete reduced the MOE due to the stiffness of PS and AS being lower than that of the NWA. The MOE of P12.5, P25, P37.5 and P50 mixes reduced by about $4.5 \%$, $13.0 \%, 28.7 \%$ and $31.5 \%$, respectively, compared to the P0. However, the MOE of LWAC ranges between 10 $\mathrm{GPa}$ and $24 \mathrm{GPa}$ is acceptable according to the CEB/FIP

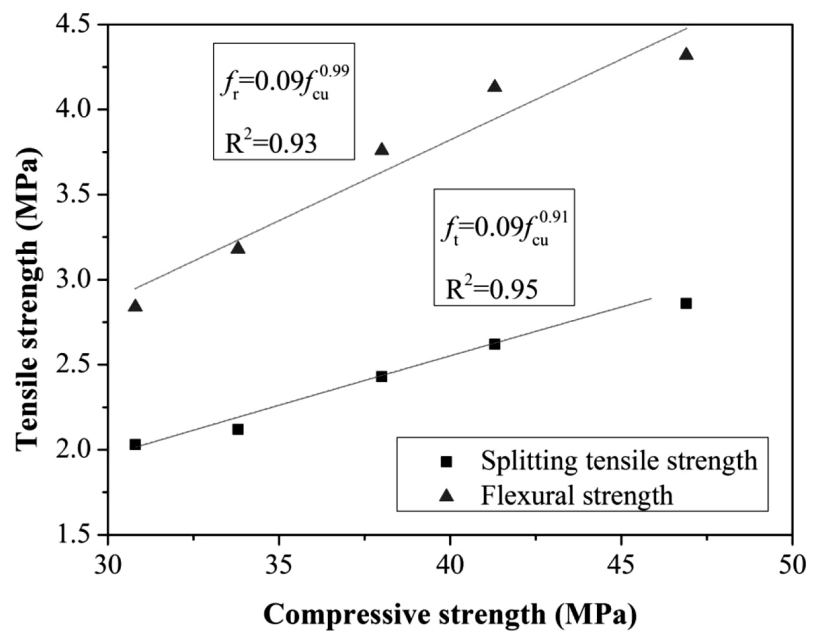

Figure 7: Relationship between compressive strength and tensile strength 


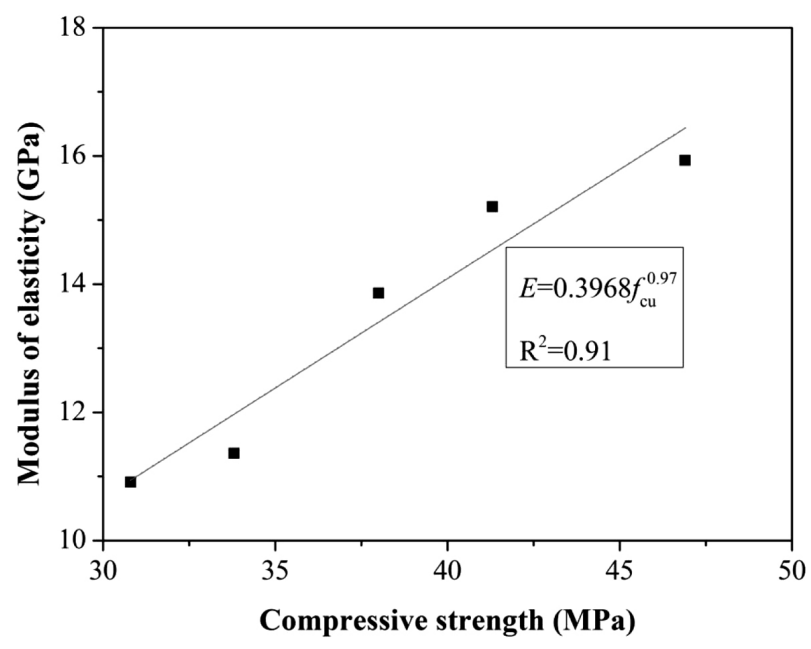

Figure 8: Relationship between the compressive strength and the MOE

manual, and the MOE of concrete containing $50 \%$ PS and $\mathrm{AS}$ in this study was still more than $10 \mathrm{GPa}$.

The relationship between the compressive strength and the MOE is presented in Figure 8, and Equation (7) is proposed to predict the MOE of concrete containing blended PS and AS.

$$
E=0.3968\left(f_{\text {cu }}\right)^{0.97}
$$

where $E$ is the MOE of the concrete (GPa) and $f_{\text {cu }}$ is the cube compressive strength $(\mathrm{MPa})$.

\subsection{Water Absorption and Porosity}

The 24-hour and 72-hour water absorptions for all mixes are shown in Figure 9. The results showed that the water absorption of concrete significantly increased with increasing the blended PS and AS content, and the 24-hour and 72-hour water absorption values of all the concretes were $3.82 \%$ to $6.59 \%$ and $4.12 \%$ to $7.64 \%$, respectively, and the open porosity varied from $8.2 \%$ to $14.6 \%$. In addition, the 24-hour water absorption

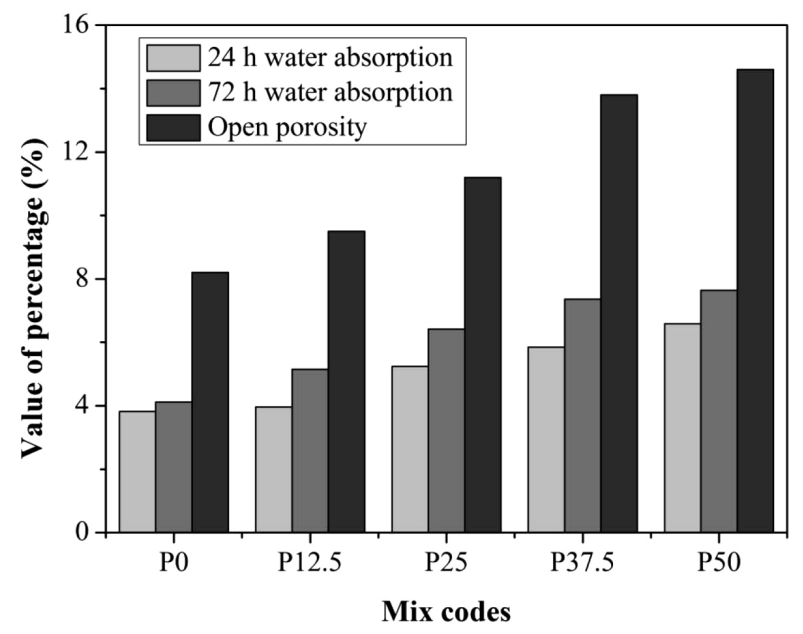

Figure 9: Percentage values of water absorption and open porosity of concrete accounted for $41.7 \%$ to $46.8 \%$ of the open porosity, while the 72-hour water absorption accounted for $50.2 \%-57.3 \%$ of the open porosity. Due to water that penetrates into concrete and other harmful ions, the water can react with concrete to affect the durability of concrete, thereby the water absorption of most of good-quality concretes usually is much lower than $10 \%$ by mass. ${ }^{17}$ As shown in Figure 9, all concretes in this study had less than $10 \%$ water absorption.

\section{CONCLUSIONS}

The incorporation of blended peach shell (PS) and apricot shell (AS) in concrete decreases the slump, density, compressive strength, splitting tensile and flexural strengths and the modulus of elasticity, while increasing the water absorption and porosity of concrete. When $50 \%$ blended PS and AS are used instead of normal weight aggregate (NWA) and sand, respectively, the reductions in slump, density, compressive strength, splitting tensile strength, flexural strength, and modulus of elasticity are $66.0 \%, 19.37 \%, 34.3 \%, 28.8 \%$, $33.6 \%$ and $31.5 \%$, respectively, and the 24-hour water absorption and porosity are $6.59 \%$ and $14.6 \%$, respectively.

The main advantage of using blended PS and AS in concrete is to reduce the density of the concrete and recycle these wastes. When the content of blended PS and AS incorporated into concrete exceeds $37.5 \%$, the oven dry density of the concrete is less than $2000 \mathrm{~kg} / \mathrm{m}^{3}$, which fulfills the requirement for a lightweight aggregate concrete (LWAC).

The properties of the aggregate have an important influence on the mechanical properties of concrete. Due to PS and AS containing many microscopic pore structures on their surface, the result is a lower strength than the NWA. In addition, they are an organic matter, which also easily weakens the bond strength between the aggregate and the cement paste. However, it is feasible to produce lightweight aggregate concrete with acceptable properties by replacing the NWA and sands with PS and $\mathrm{AS}$ at $37.5 \%$ content.

\section{Acknowledgment}

This work was supported by Graduate Student's Research and Innovation Fund of Sichuan University (grant no. 2018YJSY091), and the China Scholarship Council (CSC) Fund (grant no. 201806240037), and the Key Laboratory of Geological Hazards Mitigation for Mountainous Highway and Waterway, Chongqing Municipal Education Commission Chongqing Jiaotong University. The authors also would like to appreciate Dr. Ai Ting from the College of Architecture and Environment, Sichuan University for her assistance in conducting some of the tests in this study. 


\section{REFERENCES}

${ }^{1}$ P. Hosseini, A. Booshehrian, M. Delkash, S. Ghavami, M. K. Zanjani, Use of nano- $\mathrm{SiO}_{2}$ to improve microstructure and compressive strength of recycled aggregate concretes, the $3^{\text {rd }}$ International Symposium on Nanotechnology in Construction (NICOM 3), Heidelberg, 2009, 215-221

${ }^{2}$ A. Kanojia, S. K. Jain, Performance of coconut shell as coarse aggregate in concrete, Constr. Build. Mater., 140 (2017), 150-156, doi:10.1016/j.conbuildmat.2017.02.066

${ }^{3}$ P. Shafigh, M. Z. Jumaat, H. B. Mahmud, U. J. Alengaram, Oil palm shell lightweight concrete containing high volume ground granulated blast furnace slag, Constr. Build. Mater., 40 (2013), 231-238, doi:10.1016/j.conbuildmat.2012.10.007

${ }^{4} \mathrm{~V}$. W. Tam, Comparing the implementation of concrete recycling in the Australian and Japanese construction industries, J. Clean. Prod., 17.7 (2009), 688-702, doi:10.1016/j.jclepro.2008.11.015

${ }^{5}$ F. Pelisser, A. Barcelos, D. Santos, M. Peterson, A. M. Bernardin, Lightweight concrete production with low Portland cement consumption, J. Clean. Prod., 23 (2012), 68-74, doi:10.1016/j.jclepro. 2011.10.010

${ }^{6}$ F. Pelisser, N. Zavarise, T. A. Longo, A. M. Bernardin, Concrete made with recycled tire rubber: effect of alkaline activation and silica fume addition, J. Clean. Prod., 19 (2011), 757-763, doi:10.1016/ j.jclepro.2010.11.014

${ }^{7}$ D. E. Ramírez-Arreola, C. Sedano-de la Rosa, N. B. Haro-Mares, J. A. Ramírez-Morán, A. A. Pérez-Fonseca, J. R. Robledo-Ortíz, Compressive strength study of cement mortars lightened with foamed HDPE nanocomposites, Mater. Des., 74 (2015), 119-124, doi:10.1016/j.matdes.2015.02.013

${ }^{8}$ F. Colangelo, G. De Luca, C. Ferone, A. Mauro, Experimental and numerical analysis of thermal and hygrometric characteristics of building structures employing recycled plastic aggregates and geopolymer concrete, Energies, 6.11 (2013), 6077-6101, doi:10.3390/en6116077

${ }^{9}$ R. N. Swamy: Design for sustainable development of concrete construction, Proceedings of the Fourth International Structural Engineering and Construction Conference (ISEC 4), England, 2007, 47-54

${ }^{10}$ Y. Zhu, M. Chen, Q. Li, C. Yuan, C. Wang, A porous biomassderived anode for high-performance sodium ion batteries, Carbon, 129 (2017), 695-701, doi:10.1016/j.carbon.2017.12.103

${ }^{11}$ B. Kaynak, H. Topal, A. T. Atimtay, Peach and apricot stone combustion in a bubbling fluidized bed, Fuel Processing Technology, 86.11 (2005), 1175-1193, doi:10.1016/j.fuproc.2004.12.007

${ }^{12}$ B. T. Hosseinabady, P. Ziarati, E. Ballali, K. Umachandran, Detoxification of heavy metals from leafy edible vegetables by agricultural waste: apricot pit shell, J. Environ. Anal. Toxicol., 8.548 (2018), 2161-0525, doi:10.4172/2161-0525.1000548

${ }^{13}$ F. Wu, C. W. Liu, Z. F. Diao, F. Bo, W. Sun, X. L. Li, S. Zhao, Improvement of mechanical properties in polypropylene- and glass-fibre-reinforced peach shell lightweight concrete, Advances in Materials Science and Engineering, 11 (2018), doi:10.1155/2018/ 6250941

${ }^{14}$ J. Newman, P. Owens, Properties of Lightweight Concrete, Elsevier, 2003, 3-29

${ }^{15} \mathrm{~S}$. Bhanja, B. Sengupta, Influence of silica fume on the tensile strength of concrete, Cem. Concr. Res., 35.4 (2005), 743-747, doi:10.1016/j.cemconres.2004.05.024

${ }^{16}$ N. U. Kockal, T. Ozturan, Strength and elastic properties of structural lightweight concretes, Mater. Des., 32.4 (2011), 2396-2403, doi:10.1016/j.matdes.2010.12.053

${ }^{17}$ A. M. Neville, J. J. Brooks, Concrete Technology, Pearson Education Asia Pte Ltd., Malaysia, 1987 